\title{
Conditional Sales and Other Types of Loans in Qajar Iran
}

\author{
Nobuaki Kondo \\ Tokyo University of Foreign Studies, Tokyo, Japan \\ n-kondo@aa.tufs.ac.jp
}

\begin{abstract}
This article examines various aspects of conditional sales (bayci shart ) and other types of loans in Qajar Iran (1796-1925). Islamic law prohibited usury, but Shici jurists found a way to legalize money lending at interest. In this paper, I explore how these transactions occurred in practice and what features they had. To this end, I consider three groups of bay-i shart deeds from the National Archives of Iran, discussing how each case proceeded and how differences between cases reveal the ways in which this type of transaction functioned. While similar types of transactions were allowed in other regions and schools of law, the details of Shici legal devices were distinctive.
\end{abstract}

\section{Keywords}

Islamic Law - sale contract - law - Shicism - Qajar Iran

\section{Introduction}

Today, it is a consensus among Muslims that Islam prohibits usury. Modern Islamic banks always try to avoid loans with interest. The Qurān explicitly prohibits ribā (Qurān II 275 and III 130) and this term, ribā, has been interpreted as usury. ${ }^{1}$ However, as Maxime Rodinson showed in his famous book Islam et

1 For legal outlines of prohibit of ribā, see, J. Schacht, An Introduction to Islamic Law (Oxford: Clarendon Press, 1982): 145-6; H. Yanagihashi, イスラーム財産法 Isurâmu Zaisanhô (Tokyo: University of Tokyo Press, 2012): 235-46; M.S. Noorzoy, "Islamic Laws on Riba (Interest) and their Economic Implications." International Journal of Middle East Studies 14 (1982): 3-17. 
capitalisme, there have historically been a number of ways to lend money at interest under the rule of Islamic law. ${ }^{2}$ This was also the case in Qajar Iran. Bay' $-i$ shart, which literally means "a sale with stipulation" or "conditional sale," was one such means in Shi'i law. This mechanism was almost exactly the same as the bay ${ }^{c} i j \bar{a} \vec{i} i z$ in Hanafi law, which was developed so as not to violate Shari'a's prohibition of ribā. In previous work, I have discussed the conditional sale based on the court records of Sayyid Muhammad Ṣādiq Sangilajī and Shaykh Fażl Allāh Nūrī, who were leading mujtahids or legal experts in Tehran in the second half of the nineteenth century. ${ }^{3}$ Having acquired statistical information about this type of transactions, it is now possible to analyze its use and popularity at the sharica court in Qajar Tehran from 1860s to 1880s. The bay'-i shart was the second or third most common transaction and comprised 12 to 18 percent of the records in each register. ${ }^{4}$ This fact indicates that the bayci shart was not only wide-spread at the court but also indispensable for commercial life in Qajar Tehran. However, legality of the bay'-i sharț was sometimes challenged as Nāșir al-Dīn Shah (r. 1848-96) once prohibited the foreclosure of conditional sales' security for this reason, which historian considered it as one of the shah's achievements. ${ }^{5}$

In this paper, I attempt to explore how Islamic law was applied in the Qajar period without obstructing economic life. To this end, I examine three groups of original bay'-i shart documents from Qajar Tehran that are preserved in the National Archives of Iran, and attempt to reconstruct the transactions that are related in these materials.

As I examined previously, shari'a court records, i.e. collections of summaries of shari'a documents recorded in a court, provided information on each transaction occurred in the court but each record concerns a single transaction and does not indicate any other transactions related to them, which could occur in another court. Also, the court records sometimes refer to the foreclosure of a mortgage of bay'-i shart transactions but, even in those cases, the records do not always provide information of the original bayci shart transactions. ${ }^{6}$ However, the three sets of original bay'-i shart documents, which will be examined here, will reveal what happened in a series of transactions from the beginning to the end in a certain period of time. At the end of paper, I provide

2 M. Rodinson, Islam et Capitalisme (Paris: Demopolis, 2014): 52-4.

3 N. Kondo, Islamic Law and Society in Iran: A Social History of Qajar Tehran (Abingdon: Routledge, 2017): 79-85.

4 Ibid.: 45 .

5 Muhammad Ḥasan Khān I'timād al-Salțana, al-Ma’āsirir al-Āṣār, ed. İ. Afshār (Tehran, Asātīr, 1984-5), 176-77.

6 Kondo, Islamic Law and Society in Iran: 89. 
the text of one such bay'-i shart transaction, to illustrate the conventions and formulae used in this still little-known documentary genre.

As its name implies, bayc-i shart is categorized in Islamic law as a kind of sale (bayc). Here the term shart (condition, stipulation) alludes to the formulation khiyār al-sharț or stipulated option. Islamic law authorizes several types of khiyār, or right of rescission, and the khiyār al-sharț is one of these. The term denotes the right to cancel a contract unilaterally during a certain agreed-upon period of time. According to the prevailing opinion among Hanafi and Shafici jurists, the period should be not more than three days. ${ }^{7}$

Shi $i$ jurisprudence also admits the permissibility of khiyār al-sharț. Unlike Hanafi and Shafici legal opinion, it furthermore holds that the length of the mutually agreed-upon 'cooling-off period' during which one or other party may cancel a contract is not subject to any specified time restriction. ${ }^{8}$ However, when the seller and buyer combine the bayci shart with a lease contract for an optional period, the buyer can lend money with interest and security to the seller. For example, the owner of a house sells the house to another person by "conditional sale." This means that the owner receives money from the buyer. At the same time, the original house owner leases their own house from the buyer with rent, which means de-facto interest that the buyer must pay later. Here, the original owner continues to use their house although technically the house is owned by the buyer. Then, the original owner takes back the rights to the house from the buyer when the original owner repays the money to the buyer with the rent as interest. If the original owner cannot pay back the money during the mutually agreed-upon contract period, the sale contract will be validated, and the original owner will lose the house to the buyer, in the same way one can lose security for a loan. Therefore, relations concerning the conditional sale must be read as:

7 Yanagihashi, Zaisanhô: 286-7. Cf. Schacht, An Introduction: 152-3.

8 Muhaqqiq Ḥillī, Tarjuma-i Fārsīi-i Sharāyic al-Islām, trans. Abū al-Q̄āsim b. Aḥmad Yazdī, ed. M.T. Dānishpazhūh (Tehran: Dānishgāh-i Tihrān, 1996): 155-6; M.Ḥ. Banī Hāshimī, Tawżịh al-Masāill-i Maräji' 2 (Tehran: Islāmī, 2011): 246-7. Without agreement on the period, the sale contract is validated in three days (Hillī, Sharāyi $:$ 155-6). 
TABLE 1 Equivalent terms of simple loan and conditional sale

$\begin{array}{ll}\text { Simple loan } & \text { Conditional sale (sale and lease) } \\ \text { Borrower } & \text { Seller and leaser of the property } \\ \text { Lender } & \text { Buyer and lender of the property } \\ \text { Security } & \text { Property } \\ \text { Debt } & \text { Price of the property } \\ \text { Interest } & \text { Rent of the property } \\ \text { Loan period } & \text { Period for the right of recession and lease }\end{array}$

Although conditional sale was a type of sale contract, it provided money lending at interest with security. The borrower of the money (=seller in conditional sale) could use one's property (=mortgage) even in the loan period. This system was well-prepared for avoiding ribā in Islamic law.

Similar transactions took place in other regions, although the legal measures for legitimizing the transactions were different. An earlier example is found in one document dated 1103 from Geniza. A Muslim sold half of his house to two Jews with the right to buy it back ten years after. The Jews also permitted the Muslim to live the house by paying rent at a rate that produced five percent annual interest. ${ }^{9}$ Given that Geniza documents were composed in Judeo-Arabic, this kind of transaction evidently was not confined to Persianate societies.

In the Ottoman Empire, including the Arab regions, where Hanafi jurisprudence predominated, such transactions were named as bay'bil-istighläl (sale with mortgage) or bay' $b i^{\prime} l$-wafa (sale with the right of redemption). ${ }^{10}$ In Central Asia, another Hanafi region, the transactions were known as bay ${ }^{c} i j \bar{a} i z$ (literally, "permitted sale"). Ken'ichi Isogai has examined in detail the forms of bay'-i jāiiz deeds written in Turkic from 19th-century Khiva. According to him, bay'i jā̄iz documents did not include any conditions (sharț) for redeeming the property because Hanafi law does not permit conditions because they could harm the main contract of sale. Instead, bayci jāìz documents included a promise $\left(w a^{i} d a\right)$ to return the property to the seller if the seller repaid the

$9 \quad$ S.D. Goitein, A Mediterranean Society: The Jewish Communities of the Arab World as Portrayed in the Documents of the Cairo Geniza, vol. 4 (Berkeley: University of California Press, 1983): 87 .

10 A. Bayındır, "Bey' bi'lvefâ." In Türkiye Diyanet Vakfi İslâm Ansiklopedisi 6 (Istanbul: Türkiye Diyanet Vakfi, 1998): 20-2; A. Rafeq, "Ownership of Real Property by Foreigners in Syria, 1869 to 1873." In New Perspectives on Property and Land in the Middle East, ed. Roger Owen (Cambridge, MA: Harvard University Press. 200o): 216-7. 
price. ${ }^{11}$ In another Hanafi region, Mughal India, bay ' al-wafā was an instrument for ribā. ${ }^{12}$ The text of one such Persian document published by J.S. Grewal selfnominates as a bay' al-wafā, but the point of this document is to have one-year term for repayment, which is distinct from girwī-nāmas (mortgage deeds), the transactions which did not have a time period..$^{13}$ It was natural for Hanafis not to use khiyār for the transactions, given that, as noted above, Hanafis permitted only three days for khiyār In the case of Iran, the seller leased the property from the buyer until the seller repaid the price, and rent meant de-facto interest.

In Hadramaut, a Shafi i and Arabic-language region, the transaction was known as bay' al-'uhda. In this case, the main transaction did not concern property ownership but instead temporary custodianship and use of the property. However, in some cases, rental agreements were concluded separately for an 'uhda property, which meant a de-facto loan with interest. ${ }^{14}$ On the other hand, Oman and Zanzibar, where the Ibadi jurisprudence prevails, also had abundant examples of the loans made through use of the khiyār, which were notarized in Arabic. ${ }^{15}$

The bayci shart was thus the Shicite version of the phenomenon, widely attested not only in Persianate societies but throughout the entire Islamic world, of securitized loan at interest. Although most widely attested in the Qajar period, the bayci shart is known to have existed in earlier times: a bayci shart deed from Astarabad is dated $1119 \mathrm{AH}(1708),{ }^{16}$ and a collection of document

11 K. Isogai 磯貝健一, “Chûô-ajia komonjo kenkyû ni okeru shoshiki kenkyû no kanousei: Gôhô baibai monjo niyoru kêsu sutadi 中央アジア古文書研究における書式研究の 可能性——合法売買文書によるケース・スタディ.” In Chûô-ajia niokeru kyôzokuishiki to isuramuka-nikansuru rekishigakuteki kenkyû 中央アジアにおける共属意識 とイスラム化に関する歴史学的研究, ed. Yasushi Shinmen 新免康 (Hachioji: Chuo University, 2002): 57-63.

12 Mawlānā Shaykh Niẓām et. al. Fatāwā al-Hindìyya márūfa bi'l-Fatāwāa al-Ālamkīriyya, ed. 'A. 'Abd al-Raḥman (Beirut: 'Ilmiyya, 2000): 3: 209.

13 J.S. Grewal, In the By-Lanes of History: Some Persian Documents from a Punjabi Town (Simla: Indian Institute of Advanced Study, 1975): 47-8, 163-8.

14 L. Boxberger, "Avoiding Ribā: Credit and Custodianship in Nineteenth- and Early Twentieth Century Haduramawt." Islamic Law and Society 5 (1998): 200-1, 204-6.

15 F.A. Bishara, A Sea of Debt: Law and Economic Life in the Western Indian Ocean, 1780-1950 (Cambridge: Cambridge University Press, 2017): 90-10o. Bishara did not say explicitly that there is an Ibadi connection to khiyār transactions but at least, according to him, an Ibadi scholar, Sa'īd bin Khalfān al-Khalīlī, discussed it.

16 M. Zabāị and M. Sutūdih, Az Astārā tā Istarabād (Tehran: Anjuman-i Ās̄ār-i Millī, 1976): 7:15-7. 
specimens from late Safavid period contains three examples of bay'-i shart deeds, one of these dated $1103 \mathrm{AH}(1692) .{ }^{17}$

\section{Form of the Deeds}

The compositional form of bay'-i shart deeds reflected their legal definition. Constituting it did in Islamic law a form of bay' (sale), the bayci shart was notarized in a fashion similar to a standard sale deed.18

The main legal formula in a bayci sharț deed was the statement bifurükht bi-mubāya'a-i khiyāriyya-i sharțyya, which could be translated as "he has sold through the mubaya'a with the condition of option." This is of course similar to the main formula in a conventional sale deed, namely bifurūkht bi-mubāaya'a-i lāzima-i jāzima ("he has sold through binding and obliging mubāya'a"). Usually, the seller's name came before the main formula, though the order occasionally varied to show respect. ${ }^{19}$ After the main formula and the names of both parties, the property details were described, and were then followed by the price details, which determined the coins to be paid. In all these details, aside from the wording of the main legal formula, the form of the first part of the bay'-i shart deed was exactly the same as conventional sale deeds.

The second legal formula shart-i shar'i shud ("the legal condition is fixed"), appeared after the price was fixed, which set the terms for the recovery of the merchandise after repayment. This formula was then followed by the stipulation of a mutually-agreed fixed period (muddat-i khiyār), such as "within the six days after six months passed." If the seller repaid the price to the buyer or the buyer's representative during said fixed period, the seller repossessed the property. On the other hand, if the seller could not repay the price, the transaction was irrevocable, and the seller lost the property completely.

The third legal formula ijära-i shari shud ("the legal lease has occurred") stated that the buyer would lease back the property to the seller for the same

17 U. Riżāyī, Justārhāyē dar Sanad-shināsī-i Fārsī (Tehran: Bunyād-i Pazhūhish wa Tawși'a-i Farhang-i Waqf, 2006), 86-9. Two of the examples are titled as "a specimen of bond (șürat-i tamassuk)," which means that the compiler considers the transaction as a loan.

18 For the form of usual sale deeds from Qajar Iran, see C. Werner, "Formal Aspects of Qajar Deeds of Sale." In N. Kondo, ed. Persian Documents: Social History of Iran and Turan in the Fifteenth-Nineteenth Century (London: Routledge Curzon, 2003): 13-49. The forms of usual saled deeds and bay'-i sharț deed are also explained in U. Riżāì̄, Dar-āmadī bar Asnād-i Shar'i-i Dawla-i Qājār (Fuchu, Tokyo: ILCAA, 2008), 72-79.

19 For example, in the document in the appendix, the buyer's name Aḥmad Mĩrzā came before to show respect to the Qajar prince while the seller's name Mullā Ibrāhīm came after the main formula. 
period. After this, the rent details were described with the name and weight of coins to be paid. This lease allowed the seller (borrower) not to hand over the property to the buyer (lender) and enabled the seller (borrower) to keep the property during the fixed period.

There were some variations in the legal formulas. In Qajar Iran, the contract of settlement (șulh) could function as the contract of sale or lease. For this reason, the first and third formulas could be substituted with the șulh contract. When one used the sulh contract, the main formula was mașälaha-i khiyarriyya-i shartiiyya shud ("the settlement with the condition of option has occurred"). Also, the third formula could be changed in the șulh contract, as one can see in Document $1 .^{20}$

The bay'-i shart deeds bore the endorsements and the seals of the ulama in the upper part of the documents in the same way that conventional sale deeds had. This indicates that they were drafted at a Shari'a court. A careful examination of these documents reveals no illegal elements in the form of deeds, as they were constructed very carefully.

Like other sharica court documents, original bayci shart deeds were kept by those who had the right over the related property. Today Iranian archives is collecting such documents. Three group of documents that I examine here were preserved in the khazāna collection of National Archives of Iran. ${ }^{21}$ The name of khazāna might indicate the collection was brought from the Qajar royal treasury, but it contains private deeds, too.

\subsection{Transactions between Mullā Ibrāhìm and 'Á̇ud al-Dawla}

The first document concerns the transactions between Mullā Ibrāhīm, a Jew from Isfahan, and Sulțān Aḥmad Mīrzā 'Ażud al-Dawla, the forty-eighth son

20 "Muṣālaḥa-i shar'iyya qabūl namūd manāfa'a-i mabī mazbūr rā (He accepted to receive the profit from the above mentioned property by the șulh contract)." This is the mușălaha version of qabül-i ijära contract. In this case, the subject of the sentence is the lessee, not the lessor.

21 The archives was renamed as the National Library and Archives of Iran in 2002.

22 The National Archive of Iran no. 296002579. For a previous reference to this document, see N. Kondo, "Non-Muslims at the Shari‘a Court in Qajar Tehran." In Human Mobility and Multi-ethnic Coexistence in Middle Eastern Urban Societies 2, ed. H. Kuroki (Fuchu, Tokyo: Research Institute for Languages and Cultures of Asia and Africa, 2018): 9. 
of Fath 'Alī Shah, and the author of a famous court memoir, Tārīkh-i 'Ażudī.23 The deeds of the seven transactions, dated from 1843 to 1846 , appear on both sides of a sheet of paper. Contrary to what one might lazily presume, Mullā Ibrāhim, who was Jewish, was the seller-borrower. It is difficult to establish any information about his identity or background. ${ }^{24}$ According to the first transaction dated 7 Ziihijja $1258 \mathrm{AH} / 9$ January 1843 , notarized in the center of the right side of the sheet, he sold three shops, a bakery, a goldsmith shop, and a sandal (gìvih) shop, to 'Ażud al-Dawla for 100 tumāns by means of a bay'-i shart contract with a six-month term. Moreover, Mullā Ibrāhīm acquired six months' profits of the shop from the shops' new owner, 'Ażud al-Dawla, by paying 12 tumāns and 5000 dinnārs to him. In other words, he borrowed 100 tumāns from 'Ażud al-Dawla for six months at 25 percent per annum. The contract had another clause in the margin of the document: if the transaction contained a fraud, or the property belonged to a third party, Mullā Ibrāhīm and his brother had to pay 20o-tumān indemnity to 'Ażud al-Dawla. ${ }^{25}$

What happened next? The deed of the second transaction, written on the reverse side of the sheet, dated 28 Jumādā II 1259 AH/26 July 26 1843, states: "From the sale contract written on the front of the paper, the seller, the buyer and the owner of the shops have been exempted by each other (az ham guzashtah)." The meaning of this statement is not immediately clear. One might assume it means that Mullā Ibrāhīm repaid the debt—but this seems not to be the case: if he had done so, one would expect to see payment notarized by use of the term "cancel" ( faskh), which does not appear here; therefore, it is reasonable to assume that he did not repay the debt. Instead, this second transaction goes on to say that Mullā Ibrāhīm borrowed 1oo tumāns again from Ażud al-Dawla for six months at an interest of 12 tumāns using the same security: the shops. Therefore, we can assume that both parties actually renewed the loan after the end of the first term.

Five more transactions took place between Mullā Ibrāhīm and 'Ażud alDawla. The third transaction dated 4 Muharram 1260 AH /25 January 1844 was notarized on the reverse side. After the term of the second transaction had passed, both parties closed another similar contract. The security was the

23 Sulțān Aḥmad Mīrzā 'Ażud al-Dawla, Tārīkh-i 'Ażudī, ed. 'Abd al-Ḥusayn Navā̄ī (Tehran: Bābak, 1977); M.M. Eskandari-Qajar, "Ażod-al-Dawla, Solțān-Aḥmad Mirzā." Encyclopcedia Iranica, 2018 (http://www.iranicaonline.org/articles/azod-al-dawla-soltan-ahmad-mirza). Two persons named Mullā Ibrāhīm appear in the building survey of Tehran city of 1853; one is a jeweler and the other is a peddler. S. Sacdvandiyān and M. Ittiḥādiyya, Āmār-i Dār al-Khilāfa-i Tihrān (Tehran: Nashr-i Tārīkh-i Īrān, 1989-9o): 108-9.

25 See appendix. 
same shops as in the previous contracts. The loan amount was 112 tumāns, which was equal to the sum of the loan and the interest in the second transaction. The option period was the six days after five months passed, the interest was only 100 dīnārs, which means 0.02 percent per annum. In other words, 'Ażud al-Dawla granted grace to Mullā Ibrāhīm for the second transaction with low interest.

The fourth transaction dated 27 Rajab 126o AH/12 August 1844 is notarized in the margin of the right side. More than one month after the third transaction had passed, both parties closed another contract. The loan amount returned to the original 100 tumāns. The option period was the ten days after five months and four days passed, and the interest was 12 tumāns, which meant 28.1 percent per annum.

The fifth transaction dated 4 S Safar 1261 AH/12 February 1845 was inscribed on the reverse side. Both parties closed another contract more than six months after the previous contract. The loan amount was the same 1oo tumāns and the interest cost the same 12 tumāns. The option period was the six days after five months passed, which meant that the annual interest rate was 28.8 percent.

The sixth transaction dated ${ }_{15}$ Shabān 1261 AH/19 August 1845 was on the reverse side. The next contract ended more than six months after the previous contract. The amounts of the loan and interest, 100 tumāns and 12 tumāns, respectively, did not change. The option period was the six days after six months passed, which meant the interest rate was 24 percent per annum.

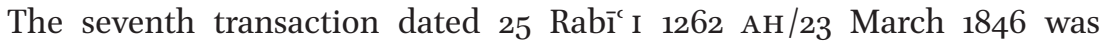
on the reverse side. The last contract was closed more than seven months after the previous contract. Again, the loan amounts and interest did not change; 100 tumāns and 12 tumāns, respectively. The option period was the three days after three months passed, which meant the annual interest rate was 48 percent.

In all six transactions, the 100-tumān loan and 12 tumāns of payable interest were fixed. The only apparent exception was the third transaction, but one can interpret that the 12 tumāns of interest was added to the original 10o-tumān loan in this case. If we calculate the total loans, Mullā Ibrāhīm borrowed 100 tumāns from 'Ażud al-Dawla for three and a half years at the annual rate of 3.4 percent. This is quite a low rate, but we do not have any information about why it should have been so low. We will see a very different situation in the next two cases.

\subsection{Transaction between Iskandar Mīrzāa, Ustād Asad Allāh and Others} Iskandar Mīrzā also belonged to the Qajar family, being the second son of Muhammad Qulī Mirzā, the second son of Fatḥ 'Alī Shah. He was the vicegovernor of the Mazandaran province during Fath 'Alì Shah's reign, but 
appeared to lose his government position during Muhammad Shah's period. ${ }^{26}$ Unlike 'Ażud al-Dawla, he was the seller-borrower, and Ustād Asad Allāh, a builder (banna $\left.\bar{a}^{\prime}\right)$ from Tehran, was the buyer-lender.

The documents related to this transaction are included in three files. Three bayci sharț transactions took place between Iskandar Mīrzā and Ustād Asad Allāh from 1837 to 1839. The first document dated 14 Rajab 1251 AH/ 5 November 1835 concerns the purchase of a house by Iskandar Mīrzā from the three daughters of a certain Mìrzā 'Alī Shīrāzì. ${ }^{27}$ This house, located in the Sangilaj district of Tehran, became the security for the later bay'-i shart transactions. The second document, dated 29 Zinhijja $1252 \mathrm{AH} / 6$ April 1837, records a further bayci $i$ shart transaction. ${ }^{28}$ Iskandar Mīrzā borrowed 18o tumāns from Ustād Asad Allāh for five months with an interest repayment of 21 tumāns and 6000 dinnārs, which meant 28.8 percent per annum. The security was the house Iskandar bought through the first document. The third document, dated 5 Sha'bān 1253 AH / 4 November 1837, was drafted on the reverse side of the second document. The document states that Iskandar Mīrzā did not clear the debt in seven months; therefore, the ownership of the house passed to Asad Allāh. As a result, Iskandar bought the house back from Asad Allāh at 200 tumāns, which was more than Iskandar's original debt but less than his total debt including interest. Moreover, Iskandar again borrowed 200 tumāns on the security of the same house and other items, such as shawls and small carpets. The interest was 25 tumāns for six months, which meant 25 percent per annum.

Since Iskandar first paid 200 tumāns and then borrowed the same amount, it is natural to suppose that both sides paid no money. In other words, this transaction was a kind of renewal of the contract, which is rather complicated because it transpired after the expiration of the previous agreement. Another point is that five tumāns out of the total payable interest of 25 tumāns went to the jurist, Mullā Muḥammad Ḥusayn Khurāsānī, who endorsed the document as "compensation for unjust transaction" (radd-i mazälim). This means that the jurist expected a future legal conflict and he would deal with it if it happened. The transaction contained a legal problem due to its complexity.

The fourth document, a deed of bayci $\mathrm{i}$ sharț, was dated 2 Rabī' I $1255 \mathrm{AH} / 16$ May 1839, more than one year after the previous term of contract

26 Mīrzā Fażl Allāh Shīrāzī Khāvarī, Tārīkh-i Znū al-Qarnayn (Tehran: Vizārat-i Farhang-i Irshād-i Islāmī, 2001): 1079. He married the daughter of 'Alī Shāh Zill al-Sulțān, who rebelled against Muḥammad Shāh.

27 The National Archives of Iran no. 296004631.

28 The National Archives of Iran no. 296oo463o. 
terminated. ${ }^{29}$ The deed did not mention the two previous transactions but the security was the same house. The difference was that three shops were added to the security for the loan, which Iskandar Mīrzā built adjacent to the house. The loan amount was 350 tumāns, the interest cost 22 tumāns, and the option period was the three days after three months passed, which means the interest rate was 25.1 percent per annum. It is probable that Iskandar Mīrzā had not repaid the second loan and was able to renew the contract by adding the shops to the security. Although the loan amount in the deed increased to $35^{\circ}$ tumāns, it is unclear how much money Iskandar actually received from Asad Allāh this time. Since the previous loan was 200 tumāns at 25 percent interest per annum, Iskandar's debt should have been more than 275 tumāns after one year and seven months. Therefore, the balance between the amount of debt and the newly added security might have been determined the loan amount.

The fifth document, a deed of settlement, was dated 2 Rabī' I $1257 \mathrm{AH} /$ 24 April 24 1841. ${ }^{30}$ Two years after the previous transaction, Ustād Asad Allāh legally owned the house and the shops because Iskandar Mīrzā could not clear his debt. The condition of the settlement was as follows: Asad Allāh paid 100 tumāns to Iskandar Mīrzā, and Iskandar Mīrzā yielded all of his rights on the house and shops, such as rent from the tenants.

Here we see what could happen if the borrower could not clear their debt within the time period stipulated in the bay'-i shart contract. According to this document, there was no doubt about the fact the lender could seize the security. However, here Iskandar Mīrzā acquired more than 100 tumāns. A buyer-lender could acquire a mortgaged house, but they could not do it prior to negotiations with the seller-borrower. According to our calculations, at that time the house and shops were worth 472 tumāns by the fourth and fifth documents. According to the first document, the house cost 240 tumāns; therefore, the value of the house including shops almost doubled.

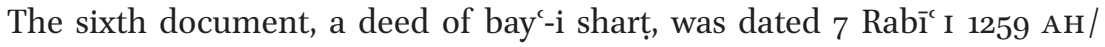
7 April $1843 .{ }^{31}$ Two years after the above-mentioned settlement, Sulțān Ahmad Mīrzā Ażud al-Dawla owned the house, though we do not have any document about how he had acquired it. According to this deed, Ażud al-Dawla borrowed 500 tumāns from a certain Āqā 'Abd al-Hamīd for three months with the interest of 37 tumāns, which means 29.6 percent per annum. A two-thirds share of the house was security for this transaction, which did not contain the shops built by Iskandar Mīrzā; Ustād Asad Allāh owned these shops. Contrary

29 The National Archives of Iran no. 29600463 o.

30 The National Archives of Iran no. 296004630.

31 The National Archives of Iran no. 2960o4652. 
to the transaction with Mullā Ibrāhīm, here we see Ażud al-Dawla as a sellerborrower, not as a buyer-lender. We do not have any information about the result of the transaction, but it is clear that the house was worth $75^{\circ}$ tumāns in total, excluding the shops. The seventh document is a sale deed dated 24 Jomādā II 1259 AH / 22 June $18433^{32}$ According to this deed, 'Ażud al-Dawla purchased the three shops from Ustād Asad Allāh at the price of 100 tumāns.

The house changed owners three times in eight years, and it was mortgaged by two different people. The price of the house rose more than three times from 240 tumāns to 750 tumāns. This case indicates the fluidity of real estate in Qajar Tehran, and one factor was no doubt the bayci shart transactions.

\subsection{Transactions between Nazar 'Alì Khän and Sulțān Aḷmad Mīrzāa 'Ázud al-Dawla ${ }^{33}$}

Naz̧ar 'Ali Khān belonged to the Bayāt tribe from Zarand, a small town located $100 \mathrm{~km}$ south-west of Tehran. He had a house in Bazar district of Tehran that was mortgaged in transactions between 1844 and 1847 .

The first transaction was a deed of bayci shart dated 26 Șafar 126o AH/ 17 March 1844 inscribed in the right side of the first document. The deed is not original but an authentic copy (savād). Naẓar 'Alī Khān borrowed 16o tumāns from 'Ażud al-Dawla at the interest of 28 tumāns using the house and ten millstones as security. Here the interest was called bāqi al-zimma, the remnants of debt. It is possible that Nażar 'Alī actually owed 'Ażud al-Dawla some money before this transaction, but in that case the deed needed to have explained the debt in more detail. According to the deed, the borrower had to repay both the original loan and the bāqi al-zimma if he wanted to recover the house and millstones. The option period was the seven days after seven months passed, which means the interest rate was 30 percent per annum. The transaction used a șulh contract with option, i.e., mușalaha-i sharțyya, for the loan. However, the borrower could not use the house because the document did not include a lease contract for the house and millstones. Therefore, another sulh contract related to the house and the mills was terminated; the borrower rented the house and the stone mills at 100 dīnārs.

The transaction included another clause in the margin. If the borrower did not repay the debt at the fixed time and still did not deliver the security to the lender, the borrower had to pay 5 tumāns per month to the lender. As we see above, lenders sometimes found it difficult to seize the loan security after the loan period had passed. This clause addressed this problem.

32 The National Archives of Iran no. 296004652.

33 The National Archives of Iran no. 296oo3210. 
The second transaction was a deed of bayci shart dated 28 Shavvāl 126o AH / 10 November 1844 notarized on the reverse side of Document 1. Eight months after the previous transaction, Naẓar 'Alī Khān and 'Ażud al-Dawla exempted each other (az ham guzashta) and revised the contract like the prince and Mullā Ibrāhīm did. However, in this case, Nazar 'Alī's loan rose from 16o to 180 tumāns, and the interest (called bāqī al-zimma) also rose from 28 to 40.5 tumāns. The security was the same house and stone mills. The option period was the eight days after eight months passed, which means that the interest rate was 33.75 percent per annum. The transaction also contained a clause delaying the security's transfer in the case of non-repayment.

The third transaction was a deed of bay'-i sharț dated 29 Shabān 1261 AH/ 2 September 1845 written on the reverse side of Document 1. Nazarar 'Alī Khān and 'Ażud al-Dawla revised the contract again after nine months and the form of the transaction was the same as the previous one. The loan amount was the same 180 tumāns, but the interest (bāqi al-zimma) had decreased to 37 tumāns. The security was the same house and stone mills. The option period was the six days after four months passed, which means the interest rate was 61.67 percent per annum.

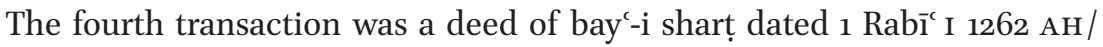
27 February 1846 written also in the reverse side of Document 1. Six months after the previous transaction, they again revised the contract. The loan amount was the same 180 tumāns and the interest was 36 tumāns. The security was the same house and stone mills. The option period was the eight days after eight months passed from 1 Muharram $1264 \mathrm{AH} / 3$ O December 1845, probably because they did not want a vacant period following the termination of the previous transaction. The interest rate was 30 percent per annum.

There is additionally a marginal note dated 23 Zīqa da 1263 AH / 2 November 1847 , indicating that the loan was unpaid, and the security was seized by the lender. However, there were some other documents drawn up prior to this note.

The fifth transaction, a deed of bay'-i sharț dated 3 Șafar 1263 AH/January 21, 1847, was notarized on a separate piece of paper (Document 2). Eleven months after the previous transaction, they closed another contract. Naẓar 'Alī Khān borrowed 200 tumāns from 'Ażud al-Dawla with the security of the same house and six stone mills (not the 10 millstones in the previous transactions). The interest was 48 tumāns and the option period was the ten days after 11 months passed from the first of the next month. Therefore, the interest rate was 26.18 percent per annum.

There is a question about the relationship between this deed and the previous deeds. This deed did not mention any previous transactions. However, according to the marginal note of the previous deed, Naẓar 'Alī Khān did not 
repay his debt until Zīqada of the same year. Although more than three months had passed since the end of the previous contract, this deed can be understood as a revised version of their previous transactions.

This document also includes a marginal note dated 1 Rabī' II $1264 \mathrm{AH} /$ 7 March 1848 by Mīrzā Abū al-Qāsim Imām Jumaa, saying "Since two months passed without repayment after the end of the period for option, the transaction was confirmed and the security was seized by Sulțān Aḥmad Mīrzā." In other words, Nazarar 'Alī Khān could not clear this debt. The following documents describe the details of the situation.

The sixth transaction was a deed of settlement between 'Azud al-Dawla and Mahdī Khān, Naẓar 'Alī's brother, dated 5 Jumādā I 1263 AH/19 April 1847 and notarized on another piece of paper (Document 3). Since Nazar 'Alī Khān had passed away by this point, his brother agreed to pay the debt to Azud al-Dawla. The security was the same house and six millstones. Mahdī Khān would pay 110 tumāns three months after the contract and an additional 122 tumāns nine months after the contract. If Mahdī Khān did not repay within the due period, 'Azud al-Dawla had the right to cancel the transaction, and in that case, the previous deed of bayci shart would be effective. Here, 'Azud alDawla tried to collect the debt from Mahdī Khān after Naẓar 'Alī's death.

An undated administrative document reveals the aftermath of the transactions. It was addressed to Tīmūr Pāshā Mākūìi, who was a member of military personnel close to the grand wazir, Hājjì Mīrzā Āqāsî. The issuer does not appear in the document, but he was probably the grand wazir because the document started "dear brother."

The document explained that Mahdī Khān escaped from Tehran without any payment. For this reason, Mullā Walī Allāh, the representative of 'Ażud alDawla, petitioned the Royal divānkhānih. The issuer sent two officials to arrest Mahdī Khān. Tīmūr Pāshā was asked to send Mahdī Khān to Tehran to deal with the debts.

The seventh transaction was a deed of settlement between 'Ażud al-Dawla and heirs of Mahdī Khān, dated 27 Sha'bān 1264 AH /29 July 1848, and notarized on yet another separate piece of paper (Document 4). The deed stated that Mahdī Khān had passed away without repayment and the house now belonged to 'Ażud al-Dawla. However, Mahdī's brother Hādī Khān, his two sisters and mother claimed that they owned one-tenth of the house. Both parties asked a specialist to estimate the value of the house. Finally, 'Ażud al-Dawla paid 6o tumāns to Hādī Khān and his family acquired full ownership of the house.

Here we know two things. First, although the transactions between 'Ażud alDawla and Mahdī Khān appear to have been no problem legally, nevertheless 'Ażud al-Dawla needed to pay 60 tumāns to his heirs. Evidently, relatives could 
easily challenge the transaction of bayc-i shart. Secondly, since one-tenth of the house was worth 60 tumāns, the total value of the house should have been 600 tumāns. Since 'Ażud al-Dawla paid first 16o tumāns and then 6o tumāns, he acquired a house of more than twice the value of his investment.

A statement by Ibrāhīm Khān b. Mușțafā Khān Afshār dated Rajab 1268 AH / April-May 1852 was the last document related to the house (Document 5). The document states that Ibrāhīm Khān purchased the former house of Naẓar 'Alī Khān from 'Azud al-Dawla and received the related documents from the prince. However, 'Azud al-Dawla still owned a piece of land adjacent to the house on the east side, and he did not have any documents proving his ownership over the land. The document was prepared to prove Azud al-Dawla's ownership, and Azud al-Dawla finally sold the house to Ibrāhīm Khān three years after the previous transaction.

All three cases examined here contained six or more transactions with complex elements. Although the legal framework of the bay'-i shart was common to all these cases, there were many differences in detail. For example, the transactions with Mullā Ibrāhīm were quite friendly to the debtor: the loan amount and interest did not change throughout the transactions. However, in the other two cases, the debts increased considerably due to the high interest rate over the course of time, and finally the debtor lost their property to the lender.

Even the term used for the interest differed. Interest was usually called $m \bar{a} l$ al-ijāra or māl al-mușālaḥa, but the transactions with Naẓar 'Alī Khān used the term bāqī al-zimma. Only Iskandar Mīrzā’s third document stipulated the radd-i mazālim. The transactions with Naẓar Khān prepared for the delay of repayment with a special clause. These facts indicate that the borrower and the lender needed to negotiate every detail of the transactions.

We can compare these documents with those in the sharīa court records. The court records are registers of issued documents at sharía courts. The form of the records varies by the registers. For example, Shaykh Fażl Allāh's register is simple for bayci $i$ shart records as follows:

A royal confidant, Āqā Mīrzā Sayyid Ibrāhīm Mustawfî Tafrishī acknowledged that he sold a half of his residence where his son lived to Hājjjī Mīrzā Yūsuf Khān b. Mushīr-i Lashkar by bayci sharț and received the price, 100 tumāns. He also rented the property (from the buyer) at 20 tumāns of the agreement fee ( $m a \bar{l}$ al-mușālaha $a$ for one year. The date 
of the acknowledgement was 22 Jumādā I, 1303. One year is the optional period for the sale. ${ }^{34}$

In this case, Sayyid Ibrāhīm borrowed 100 tumāns with 20 tumāns for one year. It is clear that these documents contain every detail of each transaction that the shari'a court records omitted. On the other hand, the shari'a court records provide statistical information.

The court records from nineteenth century Tehran contained 832 bay-i shart contracts with a lease (i.e., security and interest). Most transactions cost less than 400 tumāns, and the interest rates were usually between 10 and 30 percent per annum. The normal loan period was less than two years. Also, there are 75 records of foreclosure and 37 records of repayment in the court registers. ${ }^{35}$ Most transactions described above were in the normal range found in the shari'a court records.

Conditional sales were prevalent not only in cities but also in rural areas. The collection of $A z$ Astārā tā Istarabād documents included 15 such deeds from 1708 to 1881 . The oldest document, dated $1119 \mathrm{AH} / 17 \mathrm{O} 8$, concerns a transaction, which interest was not cash but 1 kharvār and 10 man $^{36}$ of unhulled rice. ${ }^{37}$ Most transactions were conducted over less than a year, just like the bay-i shart transactions in Tehran. ${ }^{38}$ However, two transactions were made for a longer period; nine years and ten years respectively. ${ }^{39}$ In rural areas, therefore, a longer contract of conditional sale was possible, perhaps because people did not move to other places in as a short period of time as they did in cities.

Returning to the court records from Tehran, one can find two somewhat similar but different types of contracts. The first type was a simple loan with interest. One example from Sangilajì's register was dated 7 Shavvāl 1284 AH/ 1 February $1868 .{ }^{40}$ The creditor (dāin) was Āqā Shaykh Ḥusayn, and the debtor (madyūn) was Mīrzā Buzurg Shaykh al-Islām, both of whom were probably of the 'ulama class. The debt was 310 tumāns, and the loan period was one year. At first glance, the transaction appears normal. However, when we examine the

34 M. Ittiḥādiyya and S. Rūḥī, Dar Maḥżar-i Shaykh Fażl Allāh Nūrī (Tehran: Nashr-i Tārīkh-i Īrān, 2006-o7): 53 .

35 Kondo, Islamic Law: 85-9.

$36 \quad 1$ kharvār=297 kilogram=100 man.

37 M. Żabīh and M. Sutūdih, Az Astārā tā Istarabād (Tehran: Anjuman-i Ās̄ār-i Milli, 1976): 7:15-7.

38 See, Zabīḥ and Sutūdih, Az Astārā, 6: 591-3; M. Sutūdih, Az Astārā tā Istarabād, (Tehran: Anjuman-i Ās̄ār va Mafākhir-i Farhangī, 2010-12): 9: 83-4, 10: 85-6, 89-9o.

39 Sutūdih, Az Astārā 8: 284-7, 290-4.

40 U. Riżāyī, Asnād-i Mạ̣kama-i Sayyid Șādiq Ṭabāțabāȳ̄ (Tehran: Nashr-i Ābī, 20o8-9): 29. 
debt details, we find reference to an aṣl of 250 tumāns and a far' of 60 tumāns (both rendered in siya $q$ numerals). There is no clear explanation as to the meaning of așl and far', but context suggests that the former term denotes the original debt and the latter the per-annum interest, which means 24 percent interest per year, a normal rate for loans in Qajar Tehran.

This type of transaction varied in the registers. For example, a record in Shaykh Fażl Allāh Nurìs register refers to the interest as the vajh-i muṣālaḥa. According to this record, Mīrzā 'Alī Aṣghar Kujūrī borrowed 100 tumāns from Mīrzā Muḥammad Bāqir Yūzbāshī for one year in 1304 AH/1886. The interest was 24 tumāns, which represented 24 percent interest per annum. In this case, 'Alī Aṣghar offered a one-sixth share of his house to Muhammad Bāqir as security for the loan. ${ }^{41}$ In practice, this transaction was effectively the same as a bay'-i shart because it was a loan with security and interest, but the legal device it employed was very different from the bayci sharț.

The difference between a simple loan with interest and a conditional sale might be the former's simplicity and flexibility. A simple loan could be arranged with or without interest, and with or without a pawn ( rahn), while a conditional sale could not be made without property for security. According to the sharic court records, 70 to 80 percent of simple loans did not include security and interest, while 16 to 17 percent of simple loans included interest but did not include security. Moreover, simple loans with both interest and security, which were similar to conditional sales, constituted less than 6 percent of all simple loans. ${ }^{42}$ In fact, a simple loan with a pawn was different from a conditional sale, because the pawn would be in the hands of creditors until debtors repaid their debts. Conditional sales were easier because debtors could keep their property in their hands throughout the loan period.

Moreover, one can find another type of transaction, which used the bayci sharț contract without a lease contract. For example,

Seller: Mīrzā Khān Beg, major of the royal artillery originally from Hamadan, living in Tehran. Buyer: Āqā Sayyid Nașr Allāh, merchant from Tabriz. The seller should deliver all of 1 Tabriz kharvār of sheep oil with excellent, perfect, and praised quality to the buyer three months later in Tehran (dār al-khilāfa). The price, 20 tumāns and 2 riyāls ${ }^{43}$ with Panāh-ābād silver coins with 13 nukhuds ${ }^{44}$ weight, was received. The option period

\footnotetext{
41 Ittiḥādiyya and Rūḥī, Dar Maḥżar: 128.

42 Kondo, Islamic Law: 87.

431 riya $\bar{l}=0.125$ tumāns.

441 nukhud=192 milligram.
} 
is the three days after three months passed by repaying all the price to the buyer or his legal representative. Date: The night of 1oth Ramadan, $1284 \mathrm{AH}^{45}$

The buyer paid the price for the sheep oil but could receive the oil later. The seller could recover the oil if he repaid the price within the three days after three months passed. For the seller, the transaction was beneficial because he could borrow the cash quickly. On the other hand, the buyer could receive the sheep oil at what price three months before, which was expected to be cheaper than the current market price.

This transaction was called sallam, i.e. a contract for delivery with prepayment in Islamic law. ${ }^{46}$ The fiqh texts after the ninth century considered it a kind of loan. In such cases, the buyer purchased the goods at a lower price than that in the market. The seller endured a loss at first, but he could regain some of it by using the cash he borrowed. In Qajar Tehran, this transaction was not as popular as the typical conditional sale: $5^{6}$ cases compared to 832 cases of typical conditional sales in the court records. The buyer's profits only came from the margin of the oil prices, and this transaction might not be as profitable as the typical conditional sales.

\section{Conclusion}

Unlike Islamic banking today, Qajar mujtahids allowed loans with interest using conditional sales or simple loans. After analyzing three groups of the bay'-i shart documents, one finds that there was a great variety of transactions in terms of not only the type of contract, loan periods, interest rates, and collateral, but also existence or non-existence of the indemnity or the radd-i mazālim clauses. The documents indicate that most instances of loans at interest could not be resolved with a single transaction. Instead, both parties renewed their contracts several times, although the final results of these transactions i.e. repayment or foreclosure was different according to the case. The varieties of contracts undertaken in urban areas was broad in comparison to that from rural areas. This paper has also revealed that there were two types of transactions resembling the bay'-i shart: a simple loan with interest

45 Riżāȳi, Asnād: 38.

46 Schacht, Introduction: 153; Yanagihashi, Isurâmu Zaisanhô: 396-413. According to Yanagihashi (396), the Hanafi and Malik schools called it sallam but the Shafi'i and Hanbal school called it salaf. A Shi'i fiqh book called it sallam. See Hillī, Sharāyi': 202-4. 
and a contract for delivery with prepayment. ${ }^{47}$ These were alternative ways for people in Qajar Tehran to borrow money. The variety made loan transactions more complicated.

These kinds of transactions required longer negotiations than usual contracts such as simple sales, and the professional help of the Sharía court. The prohibition of riba made the transactions more complex, and the complex transactions may have somehow obstructed the flow of economic transactions. However, these complex transactions would have benefited the 'ulama class who controlled Sharica courts. Because they stood to benefit, the presiders of the courts, the mujtahids, permitted these transactions in spite of doubts about their legality.

Although the bayc-i shart necessitated complex procedures and negotiations, this transaction was essential for the economy at that time. As mentioned above the Qajar government once prohibited the foreclosure on property of borrowers who could not repay debts by bayci shart before 1864 . However, this prohibition caused borrowers not to repay debts and, consequently, the lenders not to lend money. As a result, the economy was disrupted, and "the gates of transactions were closed." Therefore, in 1864, Nāșir al-Dīn Shah issued the royal order to permit the foreclosure after a one-year moratorium. ${ }^{48}$ It appears that this was not so effective, and the government issued the same order again in $1867 \cdot^{49}$

As Mary Sheil, who stayed in Iran as the wife of British envoy to Iran, Justin Shiel (office, 1844-54), remarked, "The entire nation seems in debt, commencing with the Shah, who is in debt to the Emperor of Russia, and ending with the humblest muleteers."50 Debts were so prevalent in Qajar society that she could not ignore them. The bay'-i shart was one of the major measures to borrow money at that time. This form of documentation was indispensable to the flow of economic transactions at the time, and jurists permitted such transactions during the period prior to the establishment of modern banks. In Qajar Iran, legal practice fulfilled two objectives: to observe the principles of Islamic law with the complex procedures and to keep the economy alive.

The moneychangers (șarrāfs) used promissory notes for lending money but I did not mention here because they were not related to the shari'a courts. For the details, see Kondo, Islamic Law: 83-4.

48 Rūznāma-i Dawlat-i Aliyya-i İrān, no.562 (3o Șafar 1281): 5-6.

49 Rūznāma-i Dawlat-i 'Aliyya-i İrān, no. 611 (10 Rajab 1284 AH ): 3.

$5^{\circ}$ M. Sheil, Glimpses of Life and Manners in Persia (London: John Murray, 1856): 141. 


\section{Appendix}

Deed of bay'-i sharț dated 7 Zīhijjja 1258 AH/9 January 1843

The National Archives of Iran no. 296002579

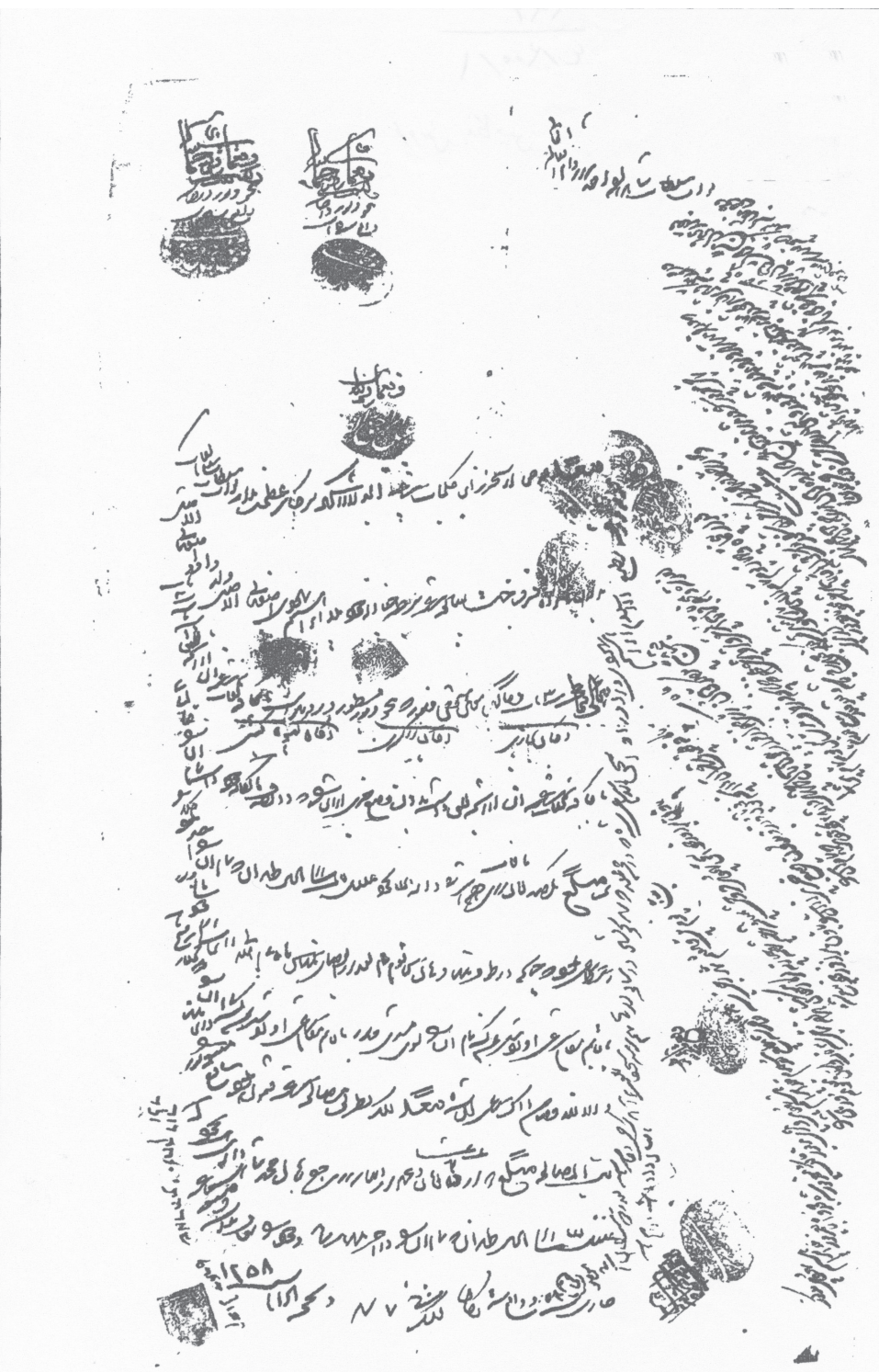

FIGURE 1 (C)THE NATIONAL LIBRARY AND ARCHIVES OF IRAN 


\section{Transcription}

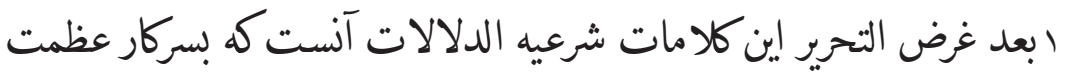

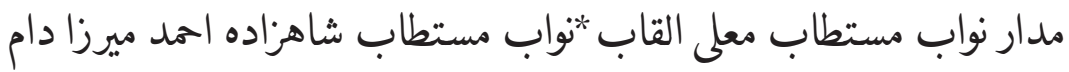
* اقباله التعالى

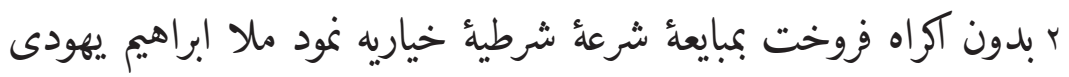
اصفهانى الاصل ولد داود اصفهانى الاصل

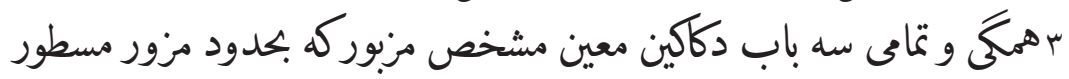

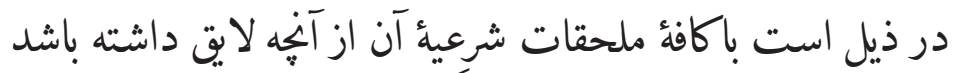

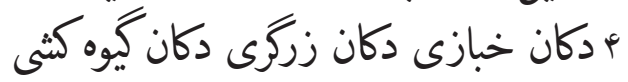

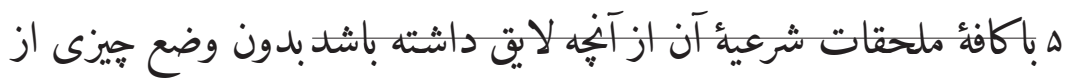
آن شود كك در تصرف مالكانه خود داشته تمام آن را بعاليشان

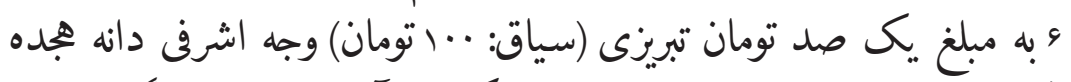

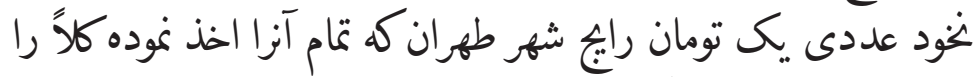

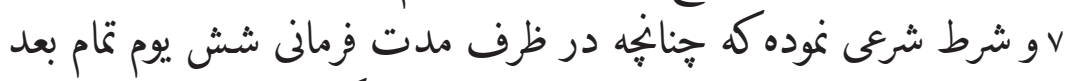

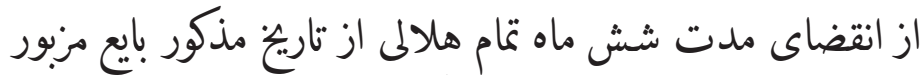

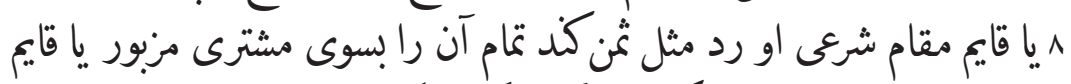

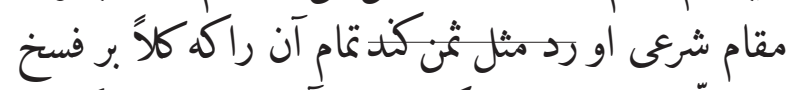

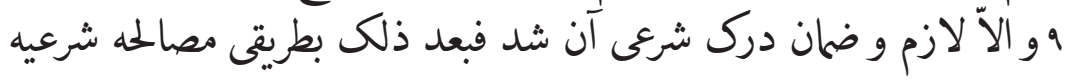

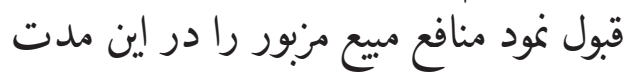

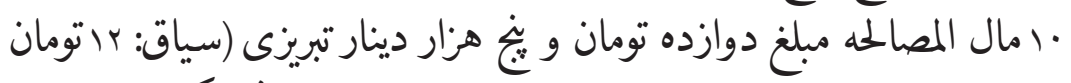

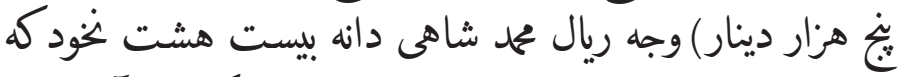

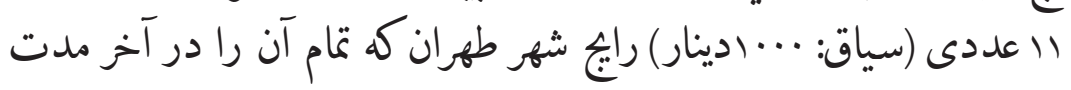

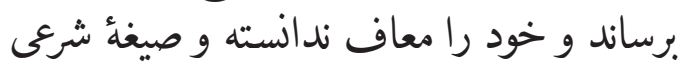

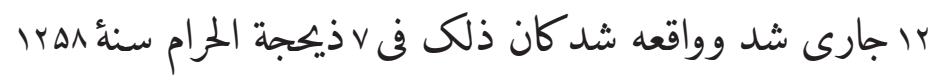




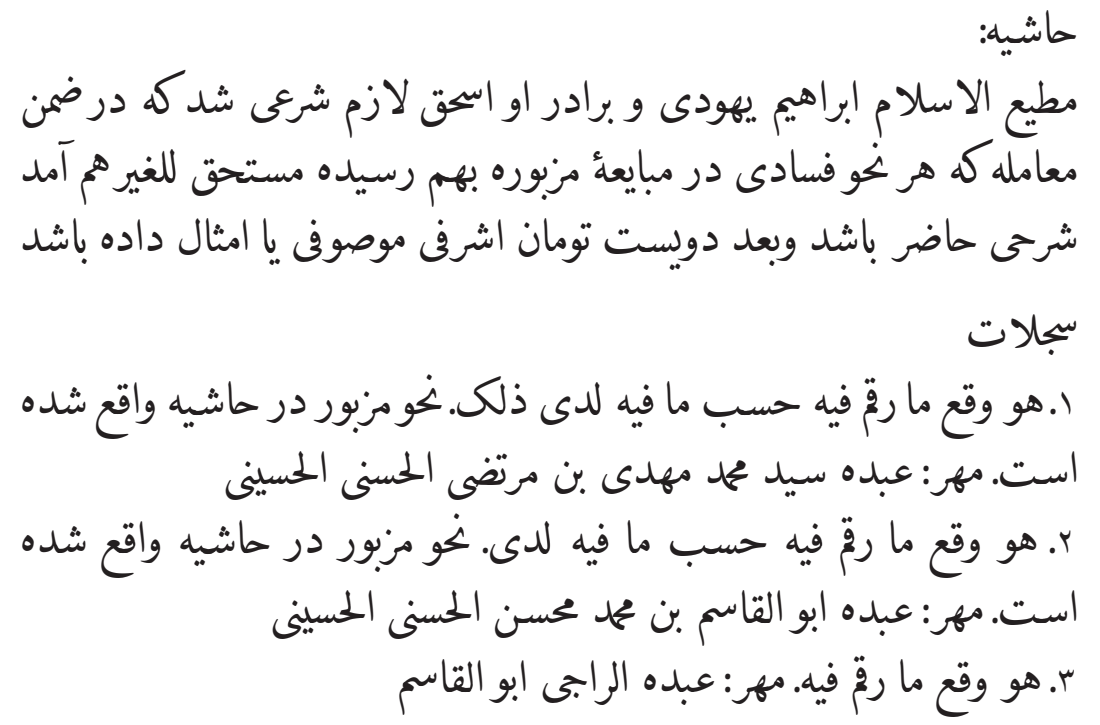

\section{Translation}

The purpose in drafting these legal documents with proofs is that Mullā Ibrāhīm, a Jew originally from Isfahan, the son of Da'ūd originally from Isfahan, willingly has sold three whole shops by conditional sale with options (mubāyaáa-i sharțiyya-i khiyāriyya) to His highness prince Aḥmad Mīrzā, May God extend his fortune. The border of the three shops is mentioned below and included all the suitable attachments by law: A baker, a goldsmith, and a sandal (givih) shop. ineluded all the suitable attachments by law.

They included everything that Mullā Ibrāhīm owned possessed. Ibrāhīm delivered them to the prince at the price of 100 Tabrizi tumāns with ashrafi silver coins, each of which has 18 nukhud weight and one tumān value in the city of Tehran. Ibrāhīm received all the prices. The legal stipulation is that the sale contract will be canceled if the seller or his legal deputy returns the money mentioned above to the buyer or his legal deputy in six days after six lunar months from the date. If not, the sale contract is binding and the seller becomes liable for the default in ownership.

Consequently, the seller accepted the profits of the shops for the period by lawful amicable agreement (mușalaḥa-i shar iyya). The price for the agreement is 12 Tabrizi tumāns and 5,000 dīnārs by the riyāl silver coins of Muhammad Shah, each of which has 28 nukhud weight and 1,0oo dīnār value in the city of Tehran. The price must be paid at the end of the term, and do not expect that he will be exempted from the payment. The contract has been concluded and becomes effective. This occurred on 7 sacred Zīịijja $125^{8} \mathrm{AH}$. 


\section{Margin:}

The (one who is) obedient of Islam, Ibrāhīm, the Jew, and his brother, Isḥaq, have a legal obligation to prepare the explanation and to pay the 200 tumāns mentioned (in the text) if a fraud has been found in the sale transaction and the property legally belongs to the third party.

\section{Endorsement:}

1. What is written here occurred in front of me like this. As it is written in the margin, it has occurred.

Seal: His servant, Sayyid Muḥammad Mahdī b. Murtaẓā al-Hasanī al-Husaynī

2. What is written here occurred in front of me. As it is written in the margin, it has occurred.

Seal: His servant, Abū al-Qāsim b. Muḥammad Muḥsin al-Hasan̄̄ al-Husaynī

3. What is written here occurred.

Seal: His servant, who hopes. Abū al-Qāsim.

\section{Acknowledgements}

I thank the European Research Commission and the Lawforms project for providing funds to publish this article, and the entire issue, in Open Access format.

\section{Bibliography}

\section{Archival Collections}

The National Archives of Iran, Tehran (renamed as the National Library and Archives of Iran).

\section{Official Gazette}

Rūznāmih-i Dawlat-i 'Aliyya-i İrān. No.472-65o. 1277-1286 AH/186o-1869. Tehran.

\section{Published Sources}

'Ażud al-Dawla, Sulțān Aḥmad Mīrzā. 1977. Tārīkh-i 'Ażudī, ed. 'Abd al-Ḥusayn Navā̄ī. Tehran: Bābak.

Banī Hāshimī, Muḥammad Ḥasan. 2011. Tawżị̆ al-Masā̉il-i Marājic, 2 vols. Tehran: Islāmī. 
Bayındır, A. 1992. Bey“ bi'lvefâ. In Türkiye Diyanet Vakfi İslâm Ansiklopedisi VI. Istanbul: Türkiye Diyanet Vakfı: 20-2.

Bishara, Fahad Ahmad. 2017. A Sea of Debt: Law and Economic Life in the Western Indian Ocean, 1780-1950. Cambridge: Cambridge University Press.

Boxberger, L. 1998. Avoiding Ribā: Credit and Custodianship in Nineteenth- and Early Twentieth Century Haḍramawt. Islamic Law and Society 5: 196-213.

Eskandari-Qajar, Manoutchehr M. 2018. 'Ażod-al-Dawlih, Solțān-Aḥmad Mirzā. Encyclopcedia Iranica (http://www.iranicaonline.org/articles/azod-al-Dawlih-soltan -ahmad-mirza).

Goitein, S.D. 1983. A Mediterranean Society: The Jewish Communities of the Arab World as Portrayed in the Documents of the Cairo Geniza, vol. 4. Berkeley: University of California Press.

Grewal, J.S. 1975. In the By-Lanes of History: Some Persian Documents from a Punjabi Town. Simla: Indian Institute of Advanced Study.

Ḥillī, Muḥaqqiq. 1996. Tarjuma-i Fārsī-i Sharāyic al-Islām, ed. Abū al-Qāsim b. Aḥmad Yazdī trans. Muhammad Taqī Dānishpazhūh, 2 vols. Tehran: Dānishgāh-i Tihrān.

Isogai, Ken'ichi 磯貝健一. 2002. Chûô-ajia komonjo kenkyû ni okeru shoshiki kenkyû no kanousei: Gôhô baibai monjo niyoru kêsu sutadi 中央アジア古文書研究 における書式研究の可能性一合法売買文書によるケース・スタディ. In Yasushi Shinmen 新免康 ed. Chûô-ajia niokeru kyôzoku-ishiki to isuramuka-nikansuru rekishigakuteki kenkyû 中央アジアにおける共属意識とイスラム化に関する歴史学 的研究. Hachioji: Chuo University: 51-66.

I'timād al-Salțanih, Muḥammad Ḥasan Khān. 1984-5. al-Ma'āsir al-Ās̄ār. Ed. Ī. Afshār. Tehran, Asātīr.

Ittihạāiyya, Manșūra and Sa'īd Rūḥī. 20o6-o7. Dar Maḥżar-i Shaykh Fażl Allāh Nūrī. Tehran: Nashr-i Tārīkh-i İrān.

Khāwarī, Mīrzā Fażl Allāh Shīrāzī. 2001. Tārīkh-i Z̄ū al-Qarnayn. Tehran: Vizārat-i Farhang-i Irshād-i Islāmī.

Kondo, Nobuaki. 2017. Islamic Law and Society in Iran: A Social History of Qajar Tehran. Abingdon: Routledge.

Kondo, Nobuaki. 2018. Non-Muslims at the Shari'a Court in Qajar Tehran. In Human Mobility and Multi-ethnic Coexistence in Middle Eastern Urban Societies 2: Tehran, Aleppo, Istanbul, and Beirut, ed. Hidemitsu Kuroki. Fuchu, Tokyo: Research Institute for Languages and Cultures of Asia and Africa: 7-21.

Niẓām, Mawlānā Shaykh et al. 2000. Fatāwā al-Hindiyya ma'rūfa bi'l-Fatāwā al-'̄Alamkīriyya, 6 vols. Beirut: 'Ilmiyya.

Noorzoy, M. Siddiq. 1982. Islamic law on Riba (Interest) and their Economic Implications. International Journal of Middle East Studies 14 (1982): 3-17. 
Rafeq, Abdul-karim. 2000. Ownership of Real Property by Foreigners in Syria 1869 to 1873. In New Perspectives on Property and Land in the Middle East, ed. Roger Owen. Cambridge: Harvard University Press: 175-239.

Riżāyī, Umīd. 2006. Justārhāȳì dar Sanad-shināsī-i Fārsī. Tehran: Bunyād-i Pazhūhish wa Tawșía-i Farhang-i Waqf.

Riżāàì, Umīd. 2008. Dar-āmadī bar Asnād-i Shar ¿̇-i Dawla-i Qājār. Fuchu, Tokyo: IlcAA. Riżāyī, Umīd. 20o8-og. Asnād-i Maḥkama-i Sayyid Ṣādiq Ṭabātabāāy. Tehran. Nashr-i Ābī.

Rodinson, Maxime. 2014 (1966). Islam et Capitalisme. Paris: Demopolis.

Sa'dvandiyān, Sīrūs and Manșūra Ittiḥādiyya. 1989-9o. Āmār-i Dār al-Khilāfa-i Tihrān. Tehran: Nashr-i Tārīkh-i İrān.

Schacht, Joseph. 1982 (1964). An Introduction to Islamic Law. Oxford: Clarendon Press.

Sheil, Mary. 1856. Glimpses of Life and Manners in Persia. London: John Murray.

Sutūdih, Manūchihr. 2010-12. Az Astārā tā Istārabād, vols. 8-10. Tehran: Anjuman-i Ās̄ār va Mafāhir-i Farhangī.

Werner, Christoph. 2003. Formal Aspects of Qajar Deeds of Sale. In Persian Documents: Social History of Iran and Turan in the Fifteenth-Nineteenth Centuries, ed. Nobuaki Kondo. London: Routledge Curzon: 13-49.

Yanagihashi, Hiroyuki 柳橋博之. 2012. Isurâmu Zaisanhô イスラーム財産法. Tokyo: University of Tokyo Press.

Zabīḥī, Masīḥ and Manūchihr Sutūdih. 1976. Az Astārā tā Istārabād, vols. 6-7. Tehran: Anjuman-i Āṣār-i Millī. 